\title{
Leptospirosis at Dr. Cipto Mangunkusumo and Persahabatan Hospital Review of 104 cases
}

\author{
Iskandar Zulkarnain
}

\begin{abstract}
Abstrak
Telah dilakukan suatu studi restropektif untuk melihat gambaran epidemiologi, klinis dan pengobatan pada 104 penderita leptospirosis yang dirawat di Rumah Sakit Cipto Mangunkusumo dan Persahabatan sejak Januari 1993 hingga Desember 1996. Dari hasil studi didapatkan bahwa $76,9 \%$ penderita adalah laki-laki dan 43,7\% adalah wanita dengan umur rata-rata 36,9 tahun (SD \pm 13) dan 43,7 tahuin ( $S D \pm 13,8$ ), sedangkan angka kejadian meningkat pada bulan Januari hingga April. Gejala klinis yang sering timbul adalah mual dengan atau tanpa muntah, dan diikuti dengan keluhan demam, nyeri otot, sufusi konjungtiva, kuning, sakit kepala, hepatomegali, batuk, perdarahan, rigor dan splenomegali; sedangkan kelainan laboratorium yang sering timbul adalah meningkatnya laju endap darah diikuti dengan meningkatnya amilase/urea darah, trombositopenia, leukositosis, meningkatnya kreatinin / bilinubin total / lipase, proteinuri, meningkatnya SGOT / SGPT dan anemia. Hasil uji MAT menunjukkan terdapatnya leptospira tunggal ( $97.56 \%$ L.bataviae), leptospira ganda (68\% L.hardjo dan bataviae), leptospira tripel (50\% L.icterohaemorrhagica, javanica dan celledoni) pada 40,4\%, 23\% dan 1,9\% penderita. Tidak terdapat perbedaan bermakna antara penderita yang tetap hidup dengan yang mati bila dihubungkan dengan jenis kelamin, umur, kadar hemoglobin, lekosit, trombosit, urea darah, kreatinin, bilinubin total, jenis antibiotika, kecuali dengan uji MAT; demikian juga antara hasil uji MAT dengan lama demam sebelum masuk rumah sakit dan lama perawatan. Tidak terdapat perbedaan hasil pengobatan baik dengan penisilin maupun antibiotika lain. termasuk sefalosporin generasi ketiga. Disimpulkan bahwa mual dengan atau tanpa muntah, demam dan nyeri otot merupakan gejala klinis yang sering muncul, sedangkan meningkatnya laju endap darah merupakan temuan laboratorium yang sering didapat. Angka kematian lebih sering didapat pada kasus dengan hasil uji MAT negatif. Penisilin masih tetap efektif untuk pengobatan.
\end{abstract}

\begin{abstract}
A restrospective study of leptospirosis cases at Cipto Mangunkusumo and Persahabatan hospital from January 1993 to December 1996 was done to determine the epidemiological, clinical and therapeutic characteristics. From 104 patients, 76,9\% were male and $43,7 \%$ were female. The average age was 36,9 years $(S D \pm 13)$ and 43.7 years $(S D \pm 13,8)$. The incidences were increased between January to April. The predominant symptoms were nausea with or without vomiting $(89.4 \%)$, followed by fever, muscle pain, conjunctival suffusion, jaundice, headache, hepatomegaly, cough, hemorrhages, rigors, and splenomegaly, respectively. The predominant laboratory abnormalities were increased erythrocyte sedimentation rate, followed by increased of amylase and blood urea, thrombocytopenia, leukocytosis, increased of creatinin, total bilirubin and lipase, proteinuria, increased of SGOT/SGPT, and anemia.Serologic tests by MAT revealed single leptospira ( $97.56 \%$ L. bataviae), double leptospira (68\% L. hardjo and bataviae). triple leptospira (50\% L. icterohaemorrhagica, javanica, and celledoni) detected in $40.4 \%, 23.1 \%$ and $1.9 \%$ patients, respectively.There were no significant differences between survive and died cases with sex, age, hemoglobin. leukocyte and thrombocyte count, blood urea, creatinin, bilirubin total, antibiotics treatment, except MAT test and also no significant difference between MAT test result with duration of fever before admitted to hospital, and length of stay of leptospirosis cases in hospital. Effectiveness of Penicillin therapy were not different with other antibiotics included cephalosporin 3rd generation $(p=0.35)$. We concluded that nause with or without vomitting, fever and muscle pain were the most common clinical presentation. Increased of erythrocyte sedimentation rates was the most common laboratory abnormality. Mortality of leptospirosis was higher in cases with negative MAT test. Procaine penicillin is still effective for leptospirosis.
\end{abstract}

Keywords: Leptospirosis, epidemiological, clinical, therapeutic characteristics

Division of Tropical and Infectious Diseases, Department of Internal Medicine Faculty of Medicine University of Indonesia, Jakarta, Indonesia
Leptospirosis is an acute generalized infectious disease caused by Spirochetes of genus Leptospira. The causative agent is Leptospira interrogans, a single species of Spirochete with multiple serotypes arranged in antigenically related groups. Over 170 
serovars and 18 serogroups have been identified for $\mathrm{L}$ interrogans. ${ }^{1,2,3,4,5}$ In human it is a zoonosis that infected from animal source. People working in a milieu that associated with rats or infected livestock with water are especially prone to infection., Serologic surveys of workers at high risk confirm that subclinical infection is common. Less than $10 \%$ of symptomatic infection result in severe, icteric illness. None of the presenting features of leptospirosis are specific, because clinical findings ranging from asymptomatic infection to renal failure and death. Where leptospirosis is common, prediction may be made on clinical suspicion and epidemiological grounds. Leptospires are sensitive to most antibiotics, and antibiotics therapy should be given as early as possible in leptospirosis. ${ }^{1,8,9,10}$ The aim of this study was to determine the epidemiological, clinical and therapeutic characteristics of leptospirosis.

\section{METHODS}

This study is a retrospective study using data from medical records of all leptospirosis cases admitted at Cipto Mangunkusumo and Persahabatan Hospital between January 1993 to December 1996. The inclusion criteria for subjects of this study were patients diagnosed as leptospirosis that confirmed by clinical features and microscopic agglutination (MAT). Data of medical records were investigated to identify their age, sex, occupation, clinical features, peripheral blood count, urinalysis, blood urea and creatinine, bilirubin, SGOT, SGPT, amylase, lipase, result of serologic test (MAT), treatment, length of stay at hospital and mortality. Statistical analysis was done using chi-square, unpaired student t-test and ANOVA.

\section{RESULT}

Sixty-three (60.6\%) patients from Cipto Mangunkusumo general hospital and forty-one (39.4\%) patients from Persahabatan Hospital were included in this study. The characteristic of 104 patients who followed the study were: $76.9 \%$ were male and $43.7 \%$ were female, the mean age was: 36.9 years ( $S D \pm 13$ ), and 43.7 years $(\mathrm{SD} \pm 13.8)$ respectively. The incidences of leptospirosis cases were increased between January to April (Figure 1).

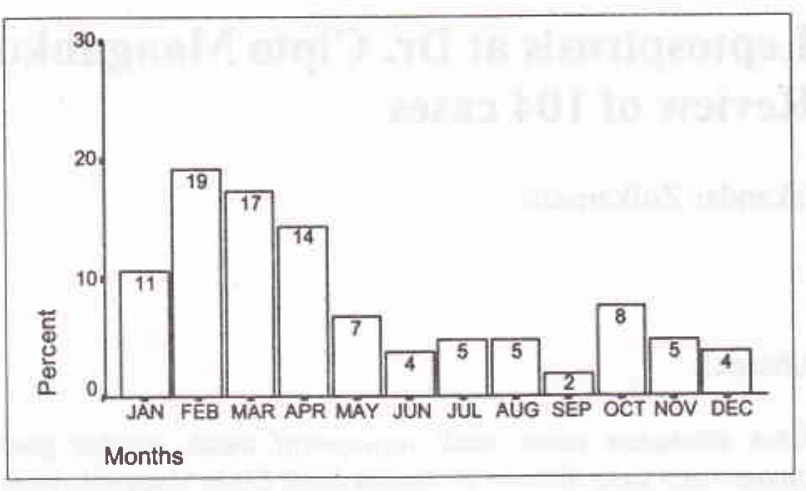

Figure 1. The incidence of leptospirosis per month

The predominant symptoms were nausea with or without vomiting $(89.4 \%)$, followed by fever, muscle pains, conjunctival suffusion, jaundice, headache, hepatomegaly, cough, hemorrhages, rigors, and splenomegaly respectively (Table 1 ).

Table 1. Clinical characteristic of leptospirosis

\begin{tabular}{lcc}
\hline Clinical characteristic & Sum $(\mathrm{n}=104)$ & $\%$ \\
\hline Nausea/ vomitting & 93 & 89.4 \\
Fever & 92 & 88.5 \\
Muscle pains & 86 & 82.7 \\
Conjunctival suffusion & 82 & 78.8 \\
Jaundice & 73 & 70.2 \\
Headache & 50 & 48.1 \\
Hepatomegaly & 39 & 37.5 \\
Cough & 34 & 32.7 \\
Hemorrhages & 25 & 24 \\
Rigors & 21 & 20.2 \\
Splenomegaly & 1 & 1 \\
\hline
\end{tabular}

The predominant laboratory abnormalities were increased erythrocyte sedimentation rate, followed by increased of amylase/ blood urea, thrombocytopenia, leukocytosis, increased of creatinin/total bilirubin/ lipase, proteinuria, increased of SGOT/SGPT, and anemia (Tabel 2).

Serologic tests by MAT revealed single leptospira $(97.56 \%$ L. bataviae), double leptospira $(68 \% \mathrm{~L}$. hardjo and bataviae), triple leptospira (50\% L. icterohaemorrhagica, javanica, and celledoni) detected in $40.4 \%, 23.1 \%$, and $1.9 \%$ patients, respectively (Table 3). 
Table 2. Laboratory abnormality of leptospirosis

\begin{tabular}{|c|c|c|c|}
\hline Laboratory abnormality & $\begin{array}{l}\text { Number laboratory } \\
\text { examination }\end{array}$ & $\begin{array}{l}\text { Number laboratory } \\
\text { abnormality }\end{array}$ & $\begin{array}{l}\text { Percentage } \\
\quad(\%)\end{array}$ \\
\hline $\begin{array}{l}\text { Increased erythrocyte sedimentation rate } \\
(\mathrm{F}>15, \mathrm{M}>10)\end{array}$ & 37 & 36 & 97.3 \\
\hline Increased of amylase $(>190 \mathrm{U} / \mathrm{l})$ & 36 & 34 & 94.4 \\
\hline Increased of blood urea (>120 mg/dl) & 103 & 97 & 94.2 \\
\hline Thrombocytopenia $(<150,000 \mathrm{~K} / \mathrm{ul})$ & 103 & 91 & 88.3 \\
\hline Leukocytosis $(>10,000 \mathrm{~K} / \mathrm{ul})$ & 104 & 91 & 87.5 \\
\hline Increased of creatinine $(>1.5 \mathrm{mg} / \mathrm{dl})$ & 103 & 87 & 84.5 \\
\hline Increased of total bilirubin ( $>1 \mathrm{mg} / \mathrm{dl})$ & 89 & 75 & 84.3 \\
\hline Increased of lipase $(>120 \mathrm{U} / 1)$ & 38 & 32 & 84.2 \\
\hline Proteinuria (protein urine $>+$ ) & 90 & 59 & 65.6 \\
\hline Increased of SGOT (>37 U/l) & 83 & 50 & 60.2 \\
\hline Increased of SGPT $(>41 \mathrm{U} / 1)$ & 83 & 39 & 47 \\
\hline Decreased of Hemoglobin $(<10 \mathrm{gr} \%)$ & 104 & 17 & 16.3 \\
\hline
\end{tabular}

Table 3. Serologic test (MAT) of leptospirosis

\begin{tabular}{lclr}
\hline Serologic test (MAT) & Percentage (\%) & Percentage serovars & $(\%)$ \\
\hline Negative & 34.6 & & \\
Single leptospira & 40.4 & bataviae & 97.56 \\
& & hardjo & 2.44 \\
Double leptospira & 23.1 & hardjo+bataviae & 68 \\
& & icterohaemorthagiae +bataviae & 12 \\
& & australis+bataviae & 4 \\
& & bataviae+tarassovi & 4 \\
& & celedoni +rachmati & 4 \\
& & javanica+bataviae & 4 \\
triple leptospira & & pomona+bataviae & 4 \\
& & icterohaemorrhagiae+javanica+celedoni & 50 \\
& \multirow{2}{*}{1.9} & icterohaemorrhagiae+bataviae+tarassovi & 50 \\
\hline
\end{tabular}

Table 4. Association between survive and died cases with variable factors

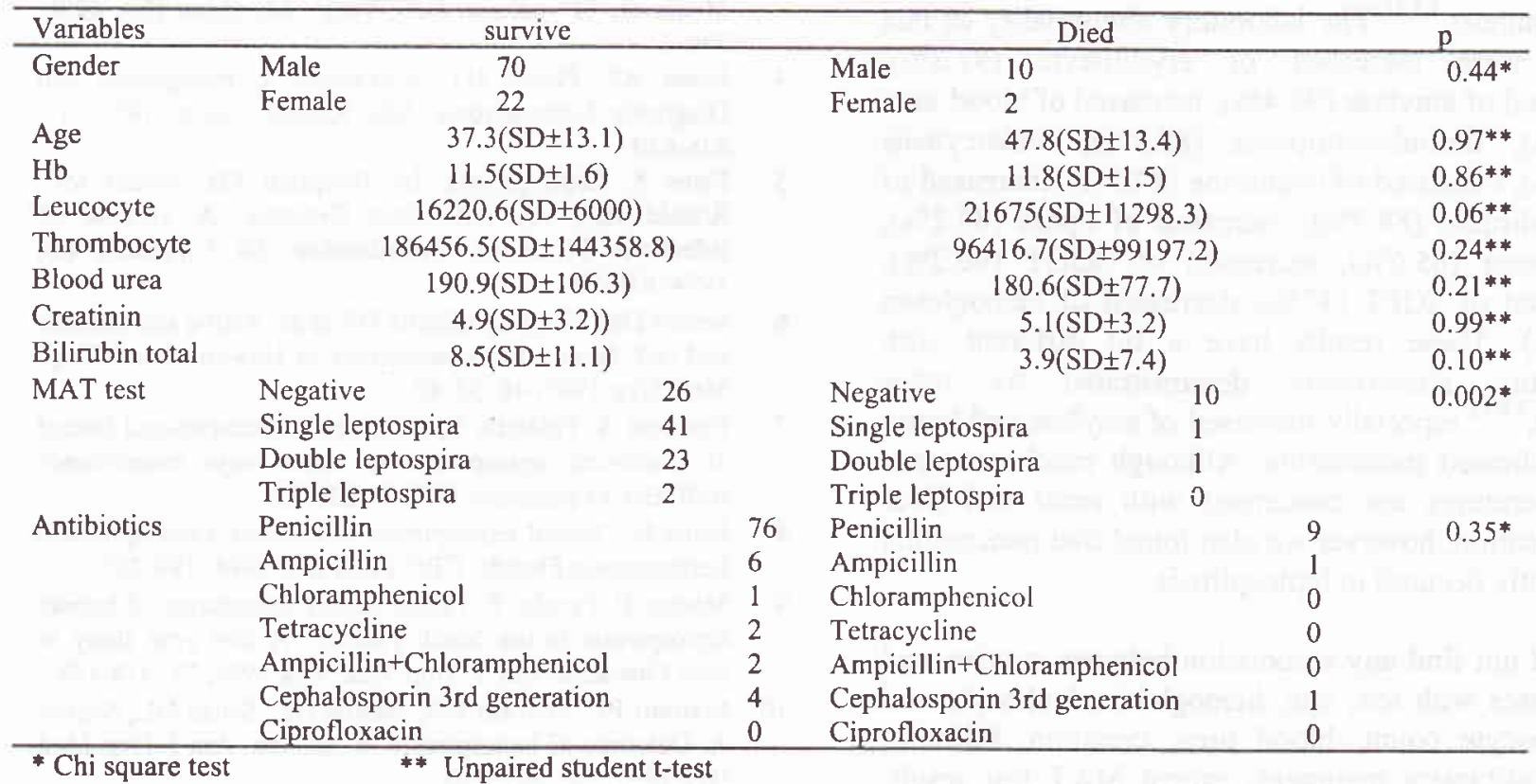


There were no significant difference between survive and died cases with sex, age, hemoglobin, leukocyte and thrombocyte count, blood urea, creatinin, bilirubin total, antibiotics treatment, except MAT test.

Table 5. Association between MAT test result with variable factors

\begin{tabular}{lccccc}
\hline Variables & \multicolumn{4}{c}{ MAT test result } & $\mathrm{p}^{*}$ \\
\hline & negative & $\begin{array}{c}\text { single } \\
\text { leptospira }\end{array}$ & $\begin{array}{c}\text { double } \\
\text { leptospira }\end{array}$ & $\begin{array}{c}\text { triple } \\
\text { leptospira }\end{array}$ \\
\hline $\begin{array}{l}\text { Duration } \\
\text { fever }\end{array}$ & 5.97 & 6.97 & 7.2 & 5 & 0.75 \\
Length of & 10.53 & 17.47 & 14.41 & 15 & 0.82 \\
stay & $(\mathrm{SD} \pm 8.89)$ & $(\mathrm{SD} \pm 7.77)$ & $(\mathrm{SD} \pm 8.58)$ & $(\mathrm{SD} \pm 11.31)$ & \\
\hline *NOVA & & & & & \\
\end{tabular}

There were no significant difference between MAT test result with duration of fever before admitted to hospital, and length of stay of leptospirosis cases in hospital.

\section{DISCUSSION}

Out of 104 cases in this study male is more frequent than female to have leptosprosis, since male patients more likely work outside and have occupational risk to be infected than female patients. ${ }^{1,9}$ The incidences of leptospirosis were increased between January to April when flood waters are high. The predominant symptoms in this study were, nausea with or without vomiting, followed by fever, muscle pains, conjunctival suffusion, jaundice. This finding is not differ with other authors. ${ }^{1,8,11}$ The laboratory abnormality of this study were increased of erythrocyte $(97.3 \%)$, increased of amylase $(94.4 \%)$, increased of blood urea $(94.2 \%)$, thrombocytopenia $(88.3 \%)$, leukocytosis $(87.5 \%)$, increased of creatinine $(84.5 \%)$, increased of total bilinbin $(84.3 \%)$, increased of lipase $(84.2 \%)$, proteinuria $(65.6 \%)$, increased of SGOT $(60.2 \%)$, increased of SGPT $(47 \%)$, decreased of hemoglobin $(16.3 \%)$. These results have a bit different with laboratory abnormality demonstrated by other authors, ${ }^{1,8,12}$ especially increased of amylase and lipase that indicated pancreatitis. Although much attention and literatures are concerned with renal and liver complication, however we also found that pancreatitis frequently occured in leptospirosis.

We did not find any association between survive and died cases with sex, age, hemoglobin, leukocyte and thrombocyte count, blood urea, creatinin, bilirubin total, antibiotics treatment, except MAT test result.
Negative MAT test was found more frequently in died cases, it seems that very low antibody in severe ill patient. ${ }^{13}$ In our study we found single $(40.4 \%)$, double $(23.1 \%)$ and triple leptospira $(1.9 \%)$ and negative leptospira (34.6\%) based on MAT test, there were no correlation with duration of fever before admitted ( $p=0.75)$ and length of stay hospitalization $(p=0.82)$. Effectiveness of Penicillin therapy were not differ with other antibiotics included cephalosporin 3rd generation $(\mathrm{p}=0.35)$.

\section{CONCLUSION}

This investigation concluded that nause with or without vomitting, fever and muscle pain were the most common clinical presentation of leptospirosis. Increased of erythrocyte sedimentation rates were the most common laboratory abnormality. Mortality of leptospirosis is more higher in cases with negative MAT test. Procaine penicillin is still effective for leptospirosis.

\section{REFERENCES}

1. Watt G. Leptospirosis. In: Strickland GT, ed. Hunter's Tropical Medicine. Philadelphia: WB Saunders, 1991; 317-23.

2. Johnson RC. Leptospirosis. In: Warren KS, Mahmoud $A A F$, eds. Tropical and geographical medicine; $2^{\text {nd }}$ edition. New York: Mc Graw Hill, 1990; 889-93.

3. Sanford JP. Leptospirosis. In: Braunwald E, Isselbacher KJ, Peterdoerf RG, eds. Harisson Principle of Internal Medicine; $13^{\text {th }}$ edition. New York : Mc Graw Hill, 1990; 740-3.

4. Syam AF, Pohan HT, Zulkarnain I. Patogenesis dan Diagnosis Leptospirosis. Maj Kedokt Indon. 1997; 47: 636-639.

5. Faine S. Leptospirosis. In: Hoeprich PD, Jordan MC, Ronald AR, eds. Infectious Diseases: A Treatise of Infectious Processes. Philadelphia: JB Lippincot Co, 1994: 619-24.

6. Sasaki DM, Pang L, Minette HP et al. Active surveillance and risk factors for leptospirosis in Hawaii. Am J Trop. Med. Hyg 1993; 48: 35-43.

7. Fontaine A, Peslerbe X, Gainere JP. Occupational hazard of unnoticed leptospirosis in water ways maintenance staff. Eur J Epidemiol 1992; 8: 228-32.

8. Faine S. Clinical leptospirosis in humans. Leptospira and Leptospirosis.Florida: CRC Press Inc, 1994; 199-227.

9. Marien F, Perolat P. Public health importance of human leptospirosis in the South Pasific : A five year study in New Caledonia. Am J Trop Med Hyg 1996; 55 : 174-178.

10. Marotto PF, Marotto MS, Santos DL, Sauza NL, Seguro A. Outcome of leptospirosis in children. Am J Trop Med Hyg $1997 ; 56: 307-310$. 
11. Heath CW, Alexander AD, Galton MM. Leptospirosis in the United States. Analysis of 438 Cases in MAN, 19491961. N Eng J Med 1965; 273: 915-22.

12. Martone, Kaufmann. Leptospirosis in humans in the United States 1974-1978. J Infect Dis 1979; 140: 1020-22.
13. Turner LH. Leptospirosis II. Serology. Trans R Soc Trop Med Hyg 1968; 62:880-99. 